Northwestern University School of Law

Northwestern University School of Law Scholarly Commons

Faculty Working Papers

2009

\title{
Valuing Foreign Lives and Civilizations in Cost- Benefit Analysis: The Case of the United States and Climate Change Policy
}

David A. Dana

Northwestern University School of Law, d-dana@law.northwestern.edu

\section{Repository Citation}

Dana, David A., "Valuing Foreign Lives and Civilizations in Cost-Benefit Analysis: The Case of the United States and Climate Change Policy" (2009). Faculty Working Papers. Paper 196.

http://scholarlycommons.law.northwestern.edu/facultyworkingpapers/196

This Working Paper is brought to you for free and open access by Northwestern University School of Law Scholarly Commons. It has been accepted for inclusion in Faculty Working Papers by an authorized administrator of Northwestern University School of Law Scholarly Commons. 
Valuing Foreign Lives and Civilizations in

Cost-Benefit Analysis: The Case of the United States and Climate Change Policy

David A. Dana

Professor of Law

Northwestern University School of Law

357 E Chicago Ave \# L225

Chicago, IL 60611-3059

d-dana@law.northwestern.edu

Telephone: 312-503-0240

Fax \# 312-503-2035 


\begin{abstract}
:
This Article explores the case for including losses of foreign (non-U.S.) lives and settlements in the estimated cost to the United States of unmitigated climate change in the future. The inclusion of losses of such foreign lives and settlements in cost benefit analysis (CBA) could have large implications not only for U.S. climate change policy but also for policies adopted by other nations and the practice of CBA generally. One difficult problem is how to assess U.S. residents' willingness to pay to prevent the losses of foreign lives and settlements. This Article discusses internet-based surveys that are a first step toward filling the empirical void in the literature regarding the measurement of U.S. residents' willingness to pay to prevent the losses of foreign lives and settlements. The survey results reported in this Article suggest that U.S. residents substantially value foreign lives and settlements. Such results make the implicit assumption of CBAs as they are currently undertaken - that U.S. residents would be willing to pay nothing to save foreign lives and settlements - very hard to maintain.
\end{abstract}

Keywords: Climate Change, Cost-Benefit Analysis, Stated Preference

Acknowledgments: This Article benefitted from generous comments from participants at the University of Chicago Olin Law \& Economics Workshop and the Midwestern Law \& Economics Association Annual Meeting. I received extremely helpful advice and comments from Kenworthey Bilz, Shari Diamond, Janice Nadler, Eric Posner, Jeff Rachlinski, and Jamie Druckman. The Searle Center on Regulation at Northwestern University provided funding to support the internet survey research. 


\section{Introduction}

How much unmitigated climate change would cost the United States in the future is an important question for those interested in the debate over how much the United States should invest now in efforts to mitigate or prevent climate change. A cost benefit analysis (CBA) for any climate change policy or regulation, in effect, compares the costs to the United States of taking mitigation and prevention measures with the costs to the United States of not taking those measures. Thus, any CBA for climate change that is or will be used for political, legal or regulatory purposes will be determined in significant part by the methodology used for estimating the costs to residents of the United States of unmitigated climate change.

The current approaches to assessing the cost to U.S. residents of unmitigated climate change in the future exclude any values for foreign lives or foreign civilizations that might be damaged or destroyed as a result of climate change. ${ }^{i}$ Current CBAs for the costs to Americans of climate change do include dollar sums to reflect estimates of what U.S. residents would pay to prevent the loss of U.S. lives and the loss of U.S. "settlements" ${ }^{\text {ii }}$ that might result from future climate change, such as deaths of U.S. residents from heat waves and losses of coastal towns and places of natural beauty within the United States from rising sea levels. What those estimates do not at all reflect, even nominally, is the welfare Americans would lose, and would be willing to pay money not to lose, when foreign lives are lost due to climate-related disease and great coastal cities and sites in foreign lands are submerged due to climate-related flooding or other adverse effects from climate change. 
This Article explores the case for including in CBAs these now-ignored losses in foreign lives and settlements as part of estimates of costs to the United States from unmitigated climate change in the future. The basic rationale for using CBAs at all -- a preference-aggregation, social-utilitarian rationale -- argues in favor of including the welfare loss U.S. residents would bear as a result of the loss of foreign lives and settlements. Moreover, there is good reason to believe that observable market data does not and cannot capture the dimensions of this welfare loss, and that survey or other stated preferences methods of assessing U.S. residents' willingness to pay to prevent such loss are therefore needed.

The question of what is and is not included in CBAs for climate change for the United States is important because CBAs frame and drive policy debates in the United States to a very substantial degree, and what the United States does or does not do regarding climate change almost certainly will have a large impact on the willingness of other countries to take measures to help prevent or mitigate climate change. Moreover, the inclusion of foreign lives and settlements in CBAs for climate change almost certainly would encourage the inclusion of foreign lives and settlements by U.S. policymakers in CBAs used to inform non-climate-change policies and by policymakers in countries other than the United States. Thus, while this Article focuses on the United States and climate change, it has implications beyond the United States and outside the (admittedly broad) context of climate change.

A key problem in including foreign lives and settlements in CBAs is how to reliably measure the willingness to pay to preserve foreign lives and settlements. In the view of some economists, "talk is cheap,” and hence surveys or other means of recording 
stated preferences are unrevealing as to people’s real preferences, that is, preferences they would really act upon. Such surveys, however, could provide useful information regarding U.S. residents' relative valuation of U.S. lives and settlements on the one hand and foreign lives and settlements on the other. But there have been no published reports of efforts to measure U.S. residents' relative willingness to pay to save U.S. and foreign lives and settlements from the adverse physical effects of climate change. Indeed, there appear to be no published studies attempting to capture U.S. residents stated willingness to pay to save foreign lives and settlements relative to U.S. lives and settlements in any context.

This Article discusses surveys I conducted that are a first step toward filling the empirical void in the literature. The survey results reported in this Article suggest that U.S. residents equally value U.S. and foreign lives and settlements. Such results do not necessarily prove that U.S. residents would individually be willing to pay the same amount of money to prevent the loss of foreign lives and settlements as they would to prevent the loss of U.S. lives and settlements. But such results do make the implicit assumption of CBAs as they are currently undertaken - that U.S. residents do not at all value foreign lives and settlements - very hard to maintain.

Part I of the Article sets the stage by briefly summarizing the best current estimates of the effects of unmitigated climate change on different regions of the world. The key point is that, under current estimates of gradual, unmitigated climate change, the direct physical impacts of climate change will be less severe in the United States than in much of the rest of the world. Part II develops the argument for considering the costs to U.S. residents of the loss of foreign lives and settlements and explains why revealed 
preferences via observable real-economy transactions cannot capture the true dimensions

of those costs. Part III explores possible approaches to surveying U.S. residents regarding foreign lives and settlements. This Part then discusses surveys that were designed to elicit information regarding U.S. residents' comparative valuation of the loss of lives and settlements within and without the United States. Part V explores some implications of the survey results.

\section{The Regional Impacts of Climate Change}

In the United States, acceptance of a precautionary approach to climate change is largely limited to certain academic and activist circles, and generally rejected by policymakers and politically-influential economists. (Kysar 2006) The assessments upon which US policymakers (and perhaps, policymakers in many other countries, either explicitly or implicitly) rely is not solely or primarily a scenario of rapid and hence broadly catastrophic climate change, but rather a blend of the catastrophic scenario and the non-catastrophic scenario, with the latter usually weighed as substantially more likely than the former. This blended approach does not ignore catastrophic possibilities but also does not “overweigh” them on the basis of an a priori commitment to precaution. iii

Three factors seem to account for most of the variance in the estimated impacts (in dollar cost terms) of the costs for different nations of climate change under this dominant blended-scenarios approach. These are: (1) coastal exposure, (2) current or baseline climate, and 3) per capita wealth or GDP. Putting these factors together, relatively poor coastal or island nations with warm climates are the most vulnerable, whereas wealthy inland nations with cold climates are the least vulnerable. (IPCC Fourth Assessment; Stern 2006) Applying the three factors to the United States leads one to 
conclude that the United States enjoys a relatively favorable position vis-à-vis the direct physical impacts of at least gradual climate change. The United States has very large coastal settlements, but it also has large inland areas with population centers and infrastructure that could be expanded if the coasts became less appealing. A large portion of the nation has a cold enough climate as a baseline that even with some warming, tropical diseases and deadly heat waves might not be a major concern. Indeed, in the now-very cold parts of the country, some studies project significant benefits in agricultural productivity and outdoor leisure time from climate change. ${ }^{\text {iv }}$ Finally, as a wealthy nation, the United States can afford investments in flooding prevention, public health, and transitional or relocation assistance that would mitigate the adverse impacts of climate change.

The leading quantitative assessment of comparative regional vulnerabilities using the blended approach remains the 2000 study by Nordhaus and Boyer. As Table One, adapted from Nordhaus and Boyer, (Nordhaus and Boyer 2000, p. 91) shows, the adverse impacts outside the United States are estimated to be much greater than the adverse impacts within the United States. According to their estimates, climate change will result in a 1.88 percent decline in GDP for the worlds’ population as a whole, but only a .45 decline in GDP for the United States.

Table One: Adverse Impacts of Unmitigated Climate Change

\begin{tabular}{|llll|}
\hline Nation/Area & $\begin{array}{l}\text { Total Loss }(\% \\
\text { of lost GDP) }\end{array}$ & Health Loss & Settlement Loss \\
\hline US & .45 & .02 & .10 \\
\hline
\end{tabular}




\begin{tabular}{|lccc|}
\hline Japan & .50 & .02 & .25 \\
\hline Europe (OECD) $\dagger$ & 2.83 & .02 & .25 \\
\hline Africa & 3.91 & 3.0 & .10 \\
\hline
\end{tabular}

† Organization for Economic Co-Operation and Development

The Nordhaus and Boyer analysis, like all the climate change cost analyses to date, does not include any welfare costs U.S. residents might bear as a result of the loss of foreign lives and settlements. The overall costs to U.S. residents of unmitigated climate change might be assessed to be significantly greater if those foreign lives and settlements costs were included, and the inclusion might change the United States' willingness to commit to binding reductions in greenhouse gas emissions as part of international accords. But the effects of the inclusion of such costs are logically a question of interest only if it is theoretically legitimate and practically possible to include such costs.

\section{The Rationale for Assessing The Costs of Foreign Lives and Settlements Through Stated Preferences}

One of the oft-cited appeals of CBAs - and welfare economics generally - is that it purports to be value "neutral” in that it generally does not ex ante or a priori exclude items for valuation on the basis of some criteria imposed by the policymaker who would make use of the CBA. That people value fancy sneakers or gigantic cars in fact means that those things and the loss of those things count and should count in CBAs, even if, on some accounts, people should not value those things highly. What matters is that people are simply willing to pay for these things. 
The neutrality principle that broadly animates the entire practice of conducting CBAs means that that willingness to pay to save foreign lives or settlements should be reflected in CBAs. That such willingness to pay does not or might not reflect "selfish" motivations but rather may reflect "altruistic" motivations is irrelevant. Willingness on the part of U.S. residents to pay to save Venice, Italy from sinking may not properly be understood as "altruistic" even if they have no intention of travelling there any time soon. The more important point, though, is that there is no sound theoretical case for excluding altruistically-driven willingness to pay from CBAs (Zerbe 2007; Johansson 1992). ${ }^{\mathrm{v}}$

One conceivable reason for excluding foreign lives and settlements, however, could be that such items are likely of so minor value to U.S. residents that it would simply not be worth the bother to include them in any overall cost estimate. After all, estimations of willingness to pay itself are not costless, in terms of the direct costs of estimations. Moreover, there are costs of introducing a new source of error into CBAs to the extent that estimations might prove difficult to reliably undertake. Eric Posner and Cass Sunstein have suggested that foreign lives and settlements should not be included in CBAs for climate change (or generally) for these reasons (Posner 2007; Posner \& Sunstein 2005).

However, even if it is true that U.S. residents on average value the loss of a foreign life or historic foreign settlement at a fraction of the value of a U.S. life or average U.S. historic settlement, the net valuation of foreign lives and settlements at risk from climate change may be very large. And it is this figure that matters. In that regard, a key point (once again) is that the direct adverse effects of climate change would be much greater outside the United States than within. One estimate of U.S. taxpayers' valuation of 
foreign lives as indicated by foreign aid expenditures is that U.S. taxpayers value foreign lives as on average worth one eighth of U.S. lives (Kopczuk et al 2005). Assume arguendo that this figure correctly captures or overstates U.S. taxpayers' or residents’ valuation of foreign lives. It is almost beyond dispute that more than eight foreign lives would be lost for every U.S. life as a result of unmitigated climate change. If so, even if a foreign life is worth only one eighth as much as a U.S. life, the loss to U.S. residents from the loss of all foreign lives would have a value to U.S. residents that is greater than the loss of all U.S. lives from unmitigated climate change. ${ }^{\mathrm{vi}}$

Moreover, it may well be that U.S. residents value foreign lives and settlements at a bigger fraction than any estimate derived from foreign aid payments would suggest. Foreign aid may not be a very good indication of what individual U.S. residents would be willing to pay to save foreign lives and settlements from climate change since, as Jason Johnston has argued, government expenditures do not necessarily mimic or perhaps come close to resembling the aggregation of individual preferences within a nation (Johnston 2007). But there are other sources of “revealed preference” evidence of U.S. residents' valuation of foreign lives and settlements, which, by extrapolation, do indeed suggest that U.S. residents would be willing to pay some amount of money to save foreign lives and settlements from loss due to climate change. For example, U.S. residents spend millions each year on foreign travel, including travel to places that are at substantial risk from climate change, such as European cities like Venice and tropical destinations like the Caribbean islands. ${ }^{\text {vii }}$ Large expenditures on travel do not directly translate into proof that U.S. residents place a large value on foreign places or that they would be willing to pay to preserve such places from climate change, but these expenditures are hard to square 
with the view that U.S. residents would be willing to pay nothing or negligible amounts to preserve foreign lives and places.

Even more powerful evidence of U.S. residents' willingness to pay is how much U.S. residents individually or through corporations and foundations give to charities serving foreign populations and to foreign family and friends in the form of individual remittances. According to one estimate, U.S. residents' private charitable giving abroad plus remittances to foreigners, with respect to developing countries, totaled $\$ 71.2$ billion in 2004 and $\$ 95.2$ billion in 2005. Aggregate giving abroad including everything private charitable giving and remittances, plus U.S. development assistance - exceeded .68 percent of GDP in 2004 and .98 percent of Gross National Income in 2005. ${ }^{\text {viii }}$ A large portion of this giving goes to countries at high risk from climate change, in particular Latin American and Middle Eastern countries and India and the Philippines. This giving, moreover, has included substantial amounts to victims of arguably climate change-related hurricanes, such as the tsunamis that have ravaged Southeast Asia. ${ }^{\text {ix }}$

There are good reasons to believe, moreover, that current patterns of giving for foreign causes and to foreigners understate U.S. residents' valuation of the foreign lives and settlements that are at risk of loss from unmitigated climate change in the future. For one thing, foreign lives and settlements that U.S. residents may value very highly - lives and settlements in the European Union countries and Japan -- have not been threatened with the kind of powerful adverse effects that climate change could impose upon them in the future and that could overwhelm even the considerable adaptive capacity of those wealthy countries. Thus, U.S. residents, individually and collectively, have not had an opportunity to show how much they value those settlements and lives and how much they 
would spend to help save the settlements or lives from severe effects from climate change in the future. If Europe were about to lose major coastal cities, U.S. residents might experience that as an important possible loss and be willing to pay to prevent that; the United States after all, entered two world wars substantially in response to crises in Europe and largely financed a massive postwar reconstruction via the Marshall Plan. Indeed, given cultural and historic ties to the United States, U.S. residents might pay a great deal to prevent losses just in the British Isles and Ireland.

Another important reason U.S. residents may not now give more to save foreign lives and settlements, particularly to poor regions such as sub-Saharan Africa, is that such giving is chilled by a kind of prisoner's dilemma dynamic. In a justly famous article, Sen argued that individuals faced with the decision to contribute to a collective good such as reductions in pollution from recycling face a classic prisoner's dilemma choice. (Sen 1973) If they knew that others would recycle all their bottles so that pollution were reduced, they could have their cake and eat it too - not have the bother of recycling their bottles but see and enjoy a reduction in pollution. On the other hand, if they do not know that others will recycle and others do not in fact recycle, they could be made worse off by recycling themselves, as they would then have assumed the burden of recycling without there being any possibility for an appreciable net reduction in pollution. These individuals would be willing to enter into an agreement with others to recycle, as they would be better off if they could see pollution reduced even if they had to assume the burden of recycling. But since binding agreements are not feasible, the individuals simply may not recycle at all. 
Extending the Sen recycling example to climate change, individual U.S. residents may not contribute to helping foreigners avoid or adapt to climate change or other challenges because they would like to assume that others - other individual U.S. residents, other foreigners, other kinds of entities (governments, domestic and foreign, or international organizations) - will make contributions that achieve that purpose so that they do not have to do so to save foreign lives and settlements. Conversely, individual U.S. residents may not contribute more because they may fear that others will not do likewise, so that the total funds available will be insufficient to make a difference in saving foreign lives and settlements. U.S. residents also may fear that their contributions will not be well-used by recipient organizations and hence will be ineffective. The climate change problem is so technically challenging that the mitigation efforts to which they could contribute may simply not have any real impact, or that at least may be a comprehensible fear.

Moreover, technical difficulties aside, money contributed to foreign charities for humanitarian purposes (climate-change related or not) could be misused as a result of corruption and conflict within the foreign countries, and U.S. residents may not give or support aid on that account. Broadly speaking, corruption is perceived to be a much greater problem in the developing countries that would be most severely impacted by unmitigated climate change, such as the countries of sub-Saharan Africa or Bangladesh. The popular press not infrequently features a report of foreign aid that has been appropriated by corrupt leaders of desperately poor countries. ${ }^{\mathrm{x}}$

Finally, willingness to pay regarding the value of foreign lives and settlements may not be revealed or fully revealed because Americans do not fully know what is 
happening outside their borders or what could happen outside their borders in the future due to unmitigated climate change. One of the fundamental puzzles of the CBA approach to social welfare assessments is whether a loss in welfare is really a loss if people do not know about it: this is another form of the proverb if a tree falls and no one hears it, has it really made a sound? Americans - many of them anyway - do not hear about and learn about every foreign famine and heat wave and flood. If they did, they might reveal a stronger valuation of foreign lives and settlements through their actions. Americans may not be aware of - or really focused upon - the risks unmitigated climate change pose to foreign lives and settlements. Moreover, for whatever reasons, Americans may believe that the United States is already providing vulnerable developing countries far more aid than is truly the case. ${ }^{\mathrm{xi}}$

Using stated preference methods such as surveys does not eliminate all of the problems that make revealed preferences - actual behavior in paying money - an imperfect means to assess the true value and hence willingness of Americans to pay to save foreign lives and settlements. But surveys can ask about particular circumstances many Americans would not hear about or that have not yet happened -- such as flooding in Europe from climate change that is so severe that Europeans cannot afford to address it. The surveys also can be constructed to try to lessen distortions from free riding and corruption/misuse of aid concerns, as discussed in Part III below.

\section{Stated Preference Surveys and the Value of Foreign Lives and Settlements}

This Part explores the problems of stated preference surveys as a means of assessing Americans' willingness to pay to prevent the loss of foreign lives and settlements to unmitigated climate change in the future. This Part considers some general problems 
with stated preference approaches and also problems that are specific to the climate change context, and considers possible responses. Finally, two surveys I administered are discussed.

\section{A. Designing and Interpreting Stated Preference Surveys}

Critics of stated preference methods argue that such methods are subject to excessive manipulation on the part of the design givers, a fact that they argue proves that the survey results are not grounded in meaningful, true preferences. For example, they point out that the order of the items to be valued on a multiple-item survey can substantially affect results: put a different item first and one gets different results. They also argue that survey respondents may provide very different responses based on minor changes in the factual information provided them, and that survey respondents also may intentionally inflate their responses if they guess that the surveys may be used to support policies or court judgments that big companies - not they - would have to pay. (Murphy et al 2005; Doshi 2008; Cross 1989)

These critics of stated preference surveys also have questioned whether surveys capture willingness to pay at all, rather than certain feelings or sensitivities to social norms. (Diamond \& Hausman 1994) In particular, they argue that results just show that respondents get a sense of "warm glow" or moral comfort in saying they would be willing to pay to prevent some harm even though they really would not be willing to pay the amount they report - or perhaps anything. They also argue that respondents offer their responses to impress the surveyors as to their generosity and conformity with social ideals, even though, again, they would not be willing to pay what they say they would be 
willing to pay. According to these critics, the results of these surveys therefore inflate the real willingness to pay of surveyed individuals. ${ }^{\text {xii }}$

The manipulation and overstatement or inflation problems, to the extent they generally do pertain, can be mitigated by reframing stated preference methods as an inquiry not into absolute willingness to pay but rather comparative willingness to pay. ${ }^{\text {xii }}$ It may be that stated preference surveys overstate both the willingness to pay to save the endangered polar bear population and the endangered salmon population, and it may well be that the particular wording of the salmon and bear surveys, even if the wording seems unimportant, may either increase or decrease the reported willingness to pay. But if we want to know something that may be important to know - how much greater or lesser is the willingness to pay to save the bears as compared to the willingness to pay to save the salmon - we can compare the relative magnitudes of the willingness to pay to save the bears and that to save the salmon. As long as the inflation or overstatement dynamic is the same in the bear as in the salmon context, that dynamic becomes irrelevant once we focus on the comparison of the two willingnesses to pay. And as long as the wording and tenor and kind of factual information provided in the salmon and bear surveys or the salmon or bear portions of a single survey is identical (or as close as possible), any effects of that wording should not affect the ratio between the two willingnesses to pay. ${ }^{\text {xiv }}$

The nature and temporal frame of climate change also presents difficult questions of survey design, regardless of whether the surveys measure absolute or relative willingness to pay. Climate change is an overarching phenomenon that will happen over a long time period, and people have difficulty reliably projecting into the distant future. (Rachlinski 2000; Dana 2003) Moreover, climate change is a massive and difficult-to-grasp 
phenomenon that even experts have difficulty describing in terms that are accessible to the lay population. And most ordinary people cannot readily imagine how any contribution they could make could affect in any meaningful way “climate change” writ large. For these reasons, it is not reasonable to assume that people can provide any intelligible answer to the broad question of how much would they pay to stop the effects of climate change, whether within a particular country such as the United States or outside. (R. Posner 2004) Indeed, one might expect a high percentage of respondents would say they are unable to or would refuse to respond.

The principal means of tackling this challenge is to structure the surveys around physical impacts that are or would be associated with climate change but that are also within or close enough to the respondents' experience that they can readily imagine and comprehend them. Thus, in the surveys discussed below, respondents are asked about adverse happenings now, not at an undefined future date, and in a particular region of the world, rather than throughout the planet. And the happenings, such as flooding or deaths from heat waves, are ones that can be readily imagined by respondents because, as we all know, even now there are major floods and deadly heat waves, at least in some parts of the world.

The level of specificity of climate change surveys is another challenging question. In order to determine how much Americans value the settlements of Italy, we could estimate and then add up the costs Americans will bear from adverse effects in any given region or part or city of that country. That approach, however, would require an enormous number of surveys. One could instead ask about a single identified and well-known city in the nation at issue - Venice in the case of Italy, for example - but then it would not be clear 
whether the answers reflected attitudes toward losses in just Venice or more broadly Italy or even more broadly Europe.

One approach would be to ask about an unspecified city or area in the nation or region at issue while giving enough facts that the respondent can imagine the general nature or character of the city or region at issue. This approach may be grounded and specific enough to allow respondents to answer meaningfully while remaining general enough to capture attitudes about regions or nations rather than attitudes about just one place. The surveys described below adopt this intermediate approach but; ideally; we would combine various approaches and compare results. More generally-worded-surveys combined with highly-place-specific ones would provide a fuller account of stated preferences. That kind of project, however, requires that the principal object of this Article first be achieved - that the costs Americans bear as a result of the loss of foreign lives and settlements be accepted as a category of costs that require real consideration and hence study.

Finally, any climate-change-related survey needs to try address two principal reasons revealed preferences may be less than fully instructive - deflated or depressed giving or support for public expenditure due to free-riding and foreign corruption concerns. If Americans are concerned about the free riding of other wealthy nations, or more generally about free riding by other potential givers whether American or foreign, that concern can be allayed by specifying that there has already been substantial giving by others. If Americans are tempted to free ride on giving by others, telling them that others have given substantially but cannot or will not give any more may also may be helpful. With regard to the foreign corruption concern at all, surveys can include wording to 
provide respondents some assurance that contributions would be well spent for their stated purposes. In the surveys discussed below, respondents are told the charity at issue already has raised much of the needed money (which address the free-riding concern somewhat) and that the charity is highly reputable (which addresses the corruption concern, at least to an extent).

\section{B. The Flood and Heat Wave Surveys}

I administered two kinds of surveys to respondents who are part of an internetbased subject pool recruited and organized by researchers at Syracuse University. The most notable feature of the demographics of the respondent groups is a very high percentage of non-minority; Caucasians. Out of the 406 respondents who completed one of the variants of what I call the "heat wave survey" and the 274 respondents who completed one of the variants of what I call the "flood survey," only a handful identified themselves as Asian-American, African-American or Latino. ${ }^{\mathrm{xv}}$ In a more racially/ethnically diverse group, particularly if some of the minorities are foreign born, we perhaps might expect higher valuations of foreign lives and settlements or of at least some kinds of foreign lives and settlements. For example, we might expect that a respondent group with a substantial percentage of Asian Americans might place a relatively high value on saving Asian settlements. The role of race and ethnicity is an interesting question but one that the demographic characteristics of our respondent groups did not allow me to consider. ${ }^{\text {xvi }}$

In the heat wave survey, the subjects received one of five variants of the survey. ${ }^{\text {xvii }}$ Each variant was the same except as to where the heat wave in question will occur. There was a variant for an unidentified City in the United States, an unidentified 
City in Southeast Asia, an unidentified City in Africa, an unidentified City in Latin

America, and an unidentified City in Europe. One of the goals of the survey was to try to isolate valuations of foreign lives as opposed to settlements, and to that end, each heat wave survey variant addressed only loss of life and did not imply that there would be a loss of historical or other structures. For example, the text of the Southeast Asia variant read as follows:

There is a City in Southeast Asia that is facing severe heat waves this summer. Several thousands of the residents of the City are at risk of death from the severe heat. The City lacks the resources to re-locate its threatened population to airconditioned structures or to cooler areas outside the City. A highly reputable charity is raising money for the emergency re-location of the City residents who are most at risk of death from the severe heat. The charity has already collected much of the needed money but requires some additional contributions to finance the emergency effort. Unless the charity can provide the needed financing for the emergency effort, it is highly likely that several thousands of the City residents will die from heatstroke. How much money would you be willing to contribute to the charity to help finance the emergency re-location?

In the flood survey, respondents received one of four variants of the survey. ${ }^{\text {xviii }}$ The variants differed only in the location of the City facing flooding, with one variant addressing an unidentified city in the United States, an unidentified city in North Africa, an unidentified city in Asia, and an unidentified city in Europe. Respondents were told the City at issue had historic significance and to underscore that point were also told that the City attracted at least 250,000 American visitors as tourists each year (which is a number of tourists that certain cities in each of these regions do attract annually). The goal of the survey was to isolate valuation of foreign settlements as opposed to foreign lives, and hence each variant of the survey provided that the structures of the City would be destroyed from flooding but the population could be re-located. For example, the text of the North Africa variant read as follows: 
There is a City in East Asia that was established hundreds of years ago and is known for its historic areas. Approximately 250,000 Americans visit the City each year. The City is being threatened by a flood that can only be prevented if new levees are constructed immediately. The population of the City could be safely re-located if there is a flood, but the flood would destroy the physical structures in the City. A highly reputable charity is collecting money to finance the construction of the levees needed to prevent the flooding. The charity has already collected much of the needed money but requires some additional contributions to have enough to finance the construction. Unless the charity can provide the needed financing, it is highly likely that the levees will not be constructed in time and that the City will be flooded. How much money would you be willing to contribute to the charity to help fund the construction of the levees?

Rather than asking respondents for a specific dollar figure, respondents were asked to pick one of several levels or brackets, ranging from "Less than $\$ 1$ " to "More than $\$ 5,000$.” The bracket approach was designed to capture the general intensity of respondents' enthusiasm for giving. In coding and comparing the results among respondent groups to generate means and test for statistically significant differences, the brackets were converted into a 1 to 7 scale, with “Less than $\$ 1$ ” equaling a 1 and "More than $\$ 5,000$ ” equaling a 7. Respondents were also asked for income and other personal information, including how much they travel outside the United States.

The results do provide some modest support for the view that Americans value American lives and settlements more than foreign ones. As Figures One and Two show, the mean contribution was highest for the American city on both the heat wave and flood surveys. As Figures Three shows, a lower percentage of respondents selected the lowest level of contribution (less than $\$ 1$ ) with respect to an American city than with respect to a city anywhere else on the heat wave survey. As Figures Four shows, on the flooding survey, a lower percentage of respondents selected the lowest level of contribution (less than \$1) for an American City than for a city in Africa or Asia. 
FIGURE ONE: Mean Monetary Contributions to Heat Wave Scenario

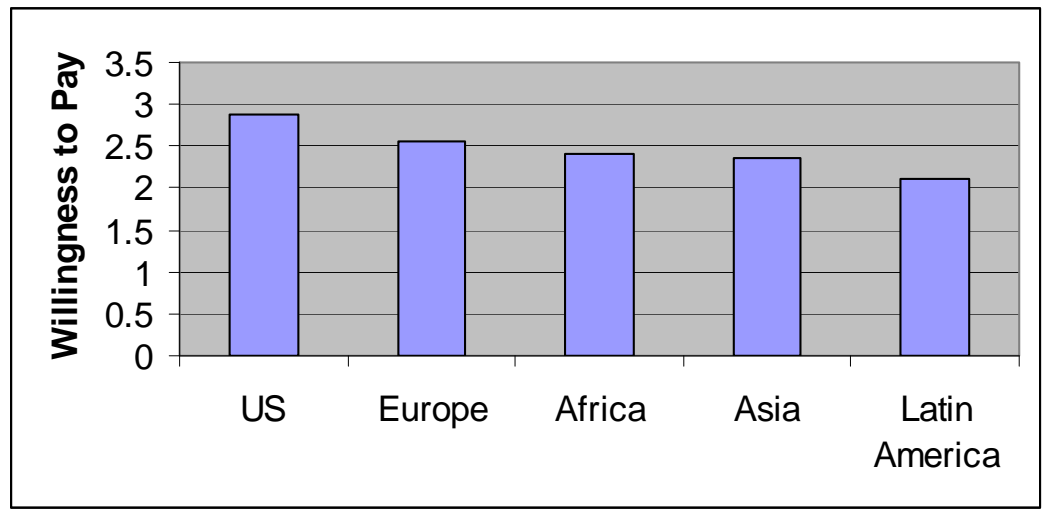

FIGURE TWO: Mean Monetary Contributions to Flooding Scenario

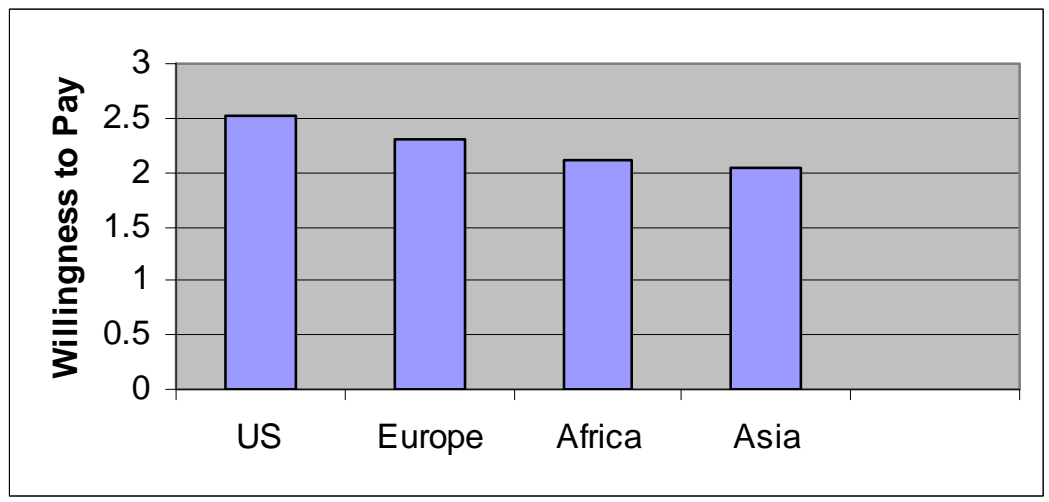

\section{FIGURE THREE}

Heat Wave Scenario: Percentage of Contributions $<\$ 1$

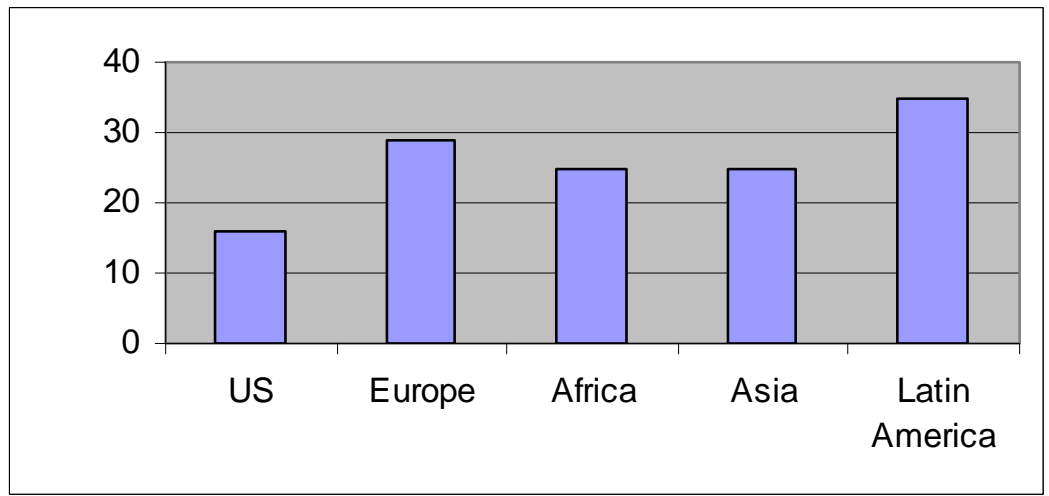

FIGURE FOUR

Flooding Scenario: Percentage of Contributions $<\$ 1$ 


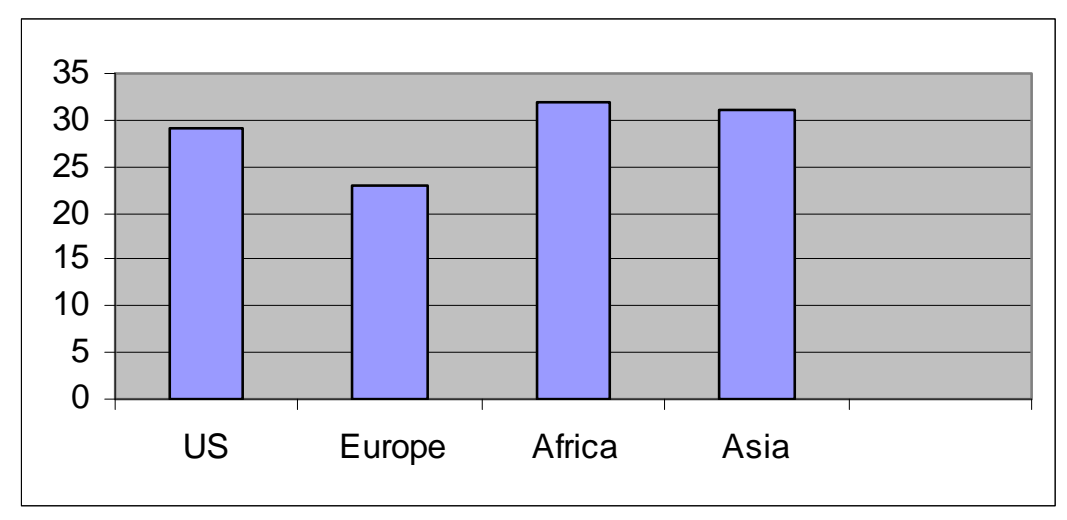

These results also suggest a certain favoritism toward Europe among respondents. The mean contribution for Europe on the heat wave study is greater than the mean contribution for Africa, Asia, or Latin America, and the difference between the European and Latin American means is statistically significant $(\mathrm{p}<.01) .{ }^{\mathrm{xix}}$ The mean contribution for Europe on the flooding survey was greater than that for Africa and Asia, and in the case of both Africa and Asia, the difference was statistically significant. An even lower percentage of respondents selected the lowest contribution level on the flooding survey for the European city than for the U.S. city (or for the city in Asia or Africa), suggesting, perhaps, then when it comes to historic settlements, European ones may be broadly more highly valued than even American ones. Overall, the results tend to support the view that assessments of Americans willingness to pay to prevent losses from climate change should take account of Europe, even though much of Europe, as of now, is too wealthy and too little threatened to plausibly make a case for needing substantial US government aid or private charity.

The most striking thing about the survey results, however, is how similar the valuations are between American lives and settlements on the one hand and foreign lives and settlements on the other. A majority of respondents (indeed $65 \%$ or more) in all the 
variants of the heat wave surveys and the flooding surveys reported that they would be willing to contribute $\$ 1$ or more; in other words, the majority clearly did not select no or zero contribution for American or foreign cities. Even more importantly, the differences between the mean responses for American lives and settlements and foreign lives and settlements on the other were not large, and in most cases were not statistically significant at any conventionally-employed significance threshold. On the heat wave survey, the only statistically significant differences between the US mean and a foreign mean was between the mean for the United States on the one hand and that for Latin America on the other. Moreover, even that statistically significant difference seems small when viewed in absolute terms (.77 on a range of 1 to 7$)$.

On the flooding survey, there was no statistically significant difference between the mean for the United States and Europe. There were statistically significant differences between the United States mean and the Asia and North Africa means, but again the differences seem small when viewed in absolute terms (.41 and .48 on a range of 1 through 7). Moreover, the statistically significant differences for Latin America on the heat wave survey and for Asia and Africa on the flooding survey may not indicate a lower willingness to pay for lives or settlements in these regions so much as greater concern about corruption and ineffectiveness of aid there (notwithstanding the survey language labeling the charity as "highly reputable”).

The ratio of the United States means to the foreign means gives the same overall impression. The mean contribution for a foreign country was not below "2" (that is, between 1 dollar and 10 dollars) on any variant of either study. The mean contribution for the United States approached but did not reach "3” (between 10 dollars and 50 
dollars). The modal response for five of the seven foreign variants was " 2 ,” whereas the modal response for the two United States variants was “3.” One possibly crude interpretation of these results is that, at most, the average valuation of an American life or settlement was no more than 50 times that of a foreign life or settlement. A 50 to 1 American/foreign valuation ratio may not obviously smack of transnational egalitarianism, but 50 to 1 is a far cry from the 2000 to 1 ratio that conceivably could be inferred from patterns of actual US foreign development aid to certain of the poorest nations of the world. ${ }^{\mathrm{xx}}$

\section{Implications of Survey Results}

The most immediate implication of the survey results is to suggest that more -and differently worded and administered surveys -- are needed to develop our understanding of U.S. residents' stated preferences. If the initial surveys reported here had suggested something consonant with current CBA practice -- that is, they had suggested a zero or near zero valuation of foreign lives and settlements-- then one might plausibly argue that further studies would not be in order. But that the reported survey results suggest a valuation completely at odds with CBA practice provides a compelling reason for investing in more research to evaluate, as best as possible, how U.S. residents do value foreign lives and settlements relative to U.S. lives and settlements in the context of climate change.

If future studies have similar results to the ones reported on here, then it would be appropriate to consider an upward revision in the estimate of net costs to the United States of unmitigated climate change. How much of an upward revision almost certainly would be a matter of dispute no matter how many stated preference surveys or other 
efforts to gather preference data are undertaken. In their 2000 estimate, Nordhaus and Boyer assign a .10 percent of GDP cost to capture the loss of value that would be attributable to loss of settlements within the U.S. If U.S. residents -- as the flood survey results discussed certainly suggest may be true -- would at least value the loss of all foreign settlement as highly as the loss of U.S. settlements from climate change, then the loss of settlement value should be at least .20, rather than .10. Within the Nordhaus and Boyer framework, that adjustment would increase the total cost assessment for the United States by $18 \%$. If one assumes a direct relationship between CBA cost estimates accepted by policymakers and the magnitude of resources the U.S. will invest to prevent or mitigate climate change, then that one change could translate into a substantial shift in U.S. policy.

Moreover, if the U.S., Europe and other countries and regions all include in their national cost estimates their residents' willingness to pay to save foreign lives and settlements, it would result in a significantly higher global estimate for the costs of unmitigated climate change.

Nor is there any reason to confine the issue of valuation of foreign lives and settlements to the policy debate surrounding climate change. Many national policies and laws have substantial extra-territorial consequences, including the loss of foreign lives and settlements. For example, if an accepted methodology were to be developed for valuing foreign lives and settlements, it could be applied beyond climate change to such issues as the (now lawful, but controversial) exporting to foreign countries of pesticides and other chemicals that are produced in but also banned within the United States. 
Finally, the reported survey results raise difficult issues about the moral and ethical limits of CBA and its basic willingness-to-pay methodology. If U.S. residents value European lives more than Asian or African ones, that does raise the ethical quandary of whether CBA should reflect a valuation that is in tension with ethical commitments to human equality. The IPCC has struggled with similar moral objections in addressing the costs of future climate change, and seems to have resolved the tension between moral theory and welfare economics in favor of the former. It arguably would be tenable, within the logic of welfare economics, to assign higher values to saving lives in wealthier countries than poorer ones because wealthy people have a higher willingness to pay to save their own lives than do poor people. The Second IPCC Report accordingly assigned a value of $\$ 1.5$ million to each life saved or lost in a developed country and a value of $\$ 150,000$ to a life in a developing country. (IPCC Second Assessment, Sunstein 2005) In response to moral objections, the IPCC has opted for a valuation of $\$ 1$ million for a life anywhere in the world, and it might well be that a similar approach would be tenable in folding in U.S. valuations of the value of foreign lives into CBA. ${ }^{\mathrm{xxi}}$

\section{Conclusion}

In the context of unmitigated climate change, the losses in welfare to U.S. residents may result more from physical impacts outside our borders than within. Yet current CBA approaches ignore that potential loss of welfare. That loss - as measured by willingness to pay to prevent the loss - cannot be readily measured by revealed preferences, and so stated preference methods, however imperfect, are important to provide a broader basis on which to approximate the magnitude of that loss. This Article has reported on results of an internet survey that suggest that U.S. residents value U.S. 
and foreign lives and settlements equally or close to equally. These survey results are the first of their kind to shed light on Americans' stated preferences regarding their evaluation of U.S. and foreign lives and settlements in the context of climate change, and, as such, they lay the groundwork for much-needed additional research. 


\footnotetext{
End Notes

${ }^{i}$ More generally, CBA for regulatory policymaking purposes in the United States simply does not address extraterritorial economic or physical impacts, and hence, not surprisingly, does not consider U.S. residents' welfare losses due to those extraterritorial impacts. A Carter-era Executive Order seemed to imply that CBAs consider extraterritorial effects, see Exec. Order No. 12,114, 44 Fed. Reg. 1957 (Jan. 4, 1979). But that Order has been substantially ignored, and extraterritoriality has not been a concern of subsequent executive orders regarding CBAs. Kysar, D. A. and Y.-W. Li (2008). Regulating from Nowhere: Domestic Environmental Law and the Nation-State Subject Cornell Law School Legal Studies Research Paper Series, available at ssrn.com/abstract=995301 (noting “tepid enforcement” of Executive Order 12114).

${ }^{\text {ii }}$ I use the term settlements to refer to human-made sites such as cities and towns and historic sites and places of distinctive natural beauty or note (which usually are also the product in part of the surrounding human culture). "Settlements" is a standard term of art in the CBA literature.

iii For a powerful argument that the current economics literature under-accounts for the extremity of adverse effects that might result from global warming given the wide range of outcomes that are conceivable, see Weitzman, M. L. (2007). The Role of Uncertainty in the Economics of Catastrophic Climate Change. AEIBrookings Joint Center Working Paper No. 07-11. From http://ssrn.com/abstract=992873.

iv See, e.g., Deschenes, O. and M. Greenstone (2004). The Economic Impacts of Climate Change: Evidence from Agricultural Profits and Random Fluctuations in Weather. MIT Department of Economics Research Paper No. 04-26. From http://ssrn.com/abstract=564722; Nordhaus, W. and J. Boyer (2000). Warming the World, MIT Press; Johnston, J. S. (2008). "Climate Change Hysteria and the Supreme Court: The Economic Impact of Global Warming on the U.S. and the Misguided Regulation of Greenhouse Gas Emissions under the Clean Air Act." Notre Dame Law Review, U of Penn, Inst for Law \& Econ Research Paper No. 08-04. 84. From SSRN: http://ssrn.com/abstract=1098476.

${ }^{\mathrm{v}}$ The principle argument against including altruistic preferences is that it results in double-counting to the extent that a CBA also includes the self-regarding preferences of the subjects of the altruistic impulses of others. But CBAs for the United States do not include the self-regarding preferences of foreign people who may be the subject of what may be regarded as the altruism of U.S. residents.

${ }^{v i}$ To the extent government aid is a meaningful representation of popular preferences or valuations regarding foreign lives, however, it may be that certain military expenditures should be included in the aid figures and not simply development or humanitarian assistance (which was the basis of the Koczuk model and extrapolation). For example, the United States has spent billions on peacekeeping in Kosovo, presumably in large part because of United States' concern about ethnic cleansing and killing in Kosovo that could occur in the absence of peacekeeping. See Bowman, S. (2003). CRS Issue Brief for Congress: Kosovo and Macedonia: U.S. and Allied Military Operations, Congressional Research Service.(estimating that Congress had already appropriated \$8.83 billion for Kosovo operations); (1999). After the War: Kosovo Peacekeeping Costs, Center for Strategic and Budgetary Assessments (estimating U.S. peacekeeping costs in Kosovo to be $\$ 2-3.5$ billion per year).

vii See, e.g., (2006). "Final US Citizen Air Traffic To Overseas Regions, Canada \& Mexico 2006, 2006 Profile of Resident Travelers Visiting Overseas Destinations.", and (2006). "U.S. Resident Travel Abroad Historical Visitation Estimates for U.S. Outbound 1996-2006 (One or More Nights)." From http:/tinet.ita.doc.gov/research. In the surveys discussed below, respondents who travelled abroad had larger mean contributions to save both U.S. and foreign lives and settlements than people who did not travel abroad, but did not have notably different ratios of mean contributions for U.S. lives and settlements in relation to mean contribution for foreign lives and settlements. The overall pool of respondents, however, contained fewer than $5 \%$ who reported frequent travel abroad, and thus it is difficult to draw any conclusions as to whether travelling abroad generally translates into greater relative valuation of and foreign lives and settlements.

viii See (2007). The Index of Global Philanthropy 2007. H. Institute: 14, 16, 26; (2006). The Index of Global Philanthropy 2006: 13-15, 31.

${ }^{\text {ix }}$ According to one estimate, the total U.S. private tsunami donations exceeded \$1.8 billion. USAID, (2006). "Tsunami Reconstruction, Two Years Later." From http://www.usaid.gov/press/factsheets/2006/fs061222.html
} 
${ }^{x}$ See, e.g., Stossel, J. and P. McMenamin. (2006). "Will More Foreign Aid End Global Poverty?" 20/20, from http://abcnews.go.com/2020.Story?id=1955664. ("So much is stolen because we rely primarily on governments to administer foreign aid, and many African governments are kleptocracies.”).

${ }^{x i}$ According to the Center on Policy Attitudes report in 2001, America "greatly" overestimated the percentage of the U.S. budget that is devoted to foreign aid. (2001). Americans on Foreign Aid and World Hunger: A Study of U.S. Public Attitudes, Program on International Policy Attitudes. From

http://www.pipa.org/archives/us opinion.php (finding that Americans overestimated aid by a factor of 20 or more).

xii There are other criticism as well, including the criticism that answer responses are insensitive to the scope of the loss to be avoided (that is, how many of an item or entity will be saved), which is also inconsistent with revealed preference, market behavior, in which willingness to pay generally corresponds to the scope or magnitude of the good or goods at issue. Whether the scope of loss or quantity objection is well-grounded depends in part on one's interpretation of the bodies of CVM studies as a whole. But even if surveys do not reflect well per-unit, scope-sensitive valuations of a particular good or goods, they may capture valuation of the general category of the good - how much people value polar bears generally, as opposed to how much they value 100 as opposed to 1000 bears. This is a plausible interpretation because published surveys have not generally given respondents enough information to assess the significance of 100 versus 1000 bears, and generally have not focused respondents on the issue by asking them to provide a valuation for 100 and 1000 bears. Instead most surveys are between-subject surveys where respondents are asked to assess the value of only one loss of a particular, stated scope or quantity. Extrapolating this point to the context of surveying about the value of foreign lives and settlements, one might reasonably argue that such studies may not capture per-unit valuation of foreign lives and settlements as much as they may capture valuation of foreign lives and settlements generally or valuation of particular categories of foreign lives and settlements (e.g., European or Latin American lives and settlements).

xiii We can obtain comparative data in stated preference studies in a number of ways. Within a single group of subjects, subjects can be asked to rank or allocate a budget with respect to various goods or to choose between two possible donations or contributions involving different goods, in which case they presumably will choose which they think is more valuable. In between-subject studies, the subjects in different groups can be given different goods to value. The former kind of survey may capture better the respondents' conscious attitudes - the attitudes they believe they have - regarding the comparative value of the items that can be saved. The latter kind of survey, by contrast, may better capture both conscious and unconscious attitudes that affect valuation. This Article discusses only between-group surveys regarding the comparative valuation of American and foreign lives and settlements: future work could and should explore whether surveys where a single group comparatively values foreign lives and settlements yields different results from between-subjects surveys.

${ }^{\text {xiv }}$ There are in fact differences in stated preference valuations for different species. For example, one study indicates that the Northern Spotted Owl is valued roughly nine times as much as Atlantic Salmon. See

Loomis, J. B. and D. S. White (1996). "Economic Benefits of Rare and Endangered Species: Summary and Meta-Analysis." Ecological Econ. 18: 199. For a recent review of the studies, see Hsuing, W. and C. R. Sunstein (2007). "Climate Change and Animals." U. Pa. L. Rev. 155: 1724.

${ }^{\mathrm{xv}}$ The surveys also asked for information regarding age and household income. The modal response for age was between 30 and 40, and the modal income response was between \$25,000 and \$50,000.

${ }^{x v i}$ The racial gaps in attitudes about public funding in the wake of hurricane Katrina suggest that the race and ethnicity of survey participants could well significantly affect willingness to pay to prevent or rectify climate-change-related natural disasters. See Dawson, M., C. Cohen, Lacewell, M.H. (2006). 2005 Racial Attitudes and the Katrina Disaster Study, University of Chicago Center for the Study of Race Politics and Culture.

, available at www.news.uchicago.edu/releases/06/images/katrina_report.doc (finding that 79\% of black respondents agreed that the "Federal Government should spend whatever's necessary to rebuild and restore people to their homes in Katrina's aftermath" but only 33\% of white respondents agreed with that proposition).

xvii The number of respondents who completed each variant was: United States, 85, Europe, 79, Africa, 81, Latin America, 80, Asia, 76.

xviii The number of respondents who completed each variant was: United States, 66, Europe, 72, Asia, 68, Africa, 73. 
xix Throughout the paper, the standard used for statistical significance is $\mathrm{p}<.01$.

${ }^{x x i}$ While one could argue that surveying people about their valuation of foreign lives degrades the value of human life in some way and may even make visible racial or cultural preferences that are ethically problematic, see, e.g., Ackerman, F. and L. Heinzerling (2002). "Pricing the Priceless: Cost-Benefit Analysis of Environmental Protection." University of Pennsylvania Law Review 150: 1562-78. (arguing that cost-benefit analysis devalues human life and is contrary to common intuitions and values). It would seem even more ethically problematic to proceed on the assumption that only U.S. lives have value to U.S. residents and that foreign lives have zero value, which appears to be the assumption of current CBA practice. 


\section{References}

Dana, D. "A Behavioral Economic Defense of the Precautionary Principle" NW L REV

Diamond, P. A. and J. A. Hausman (1994). "Contingent Valuation: Is Some Number Better Than No Number?" J. Econ. Persp. 8: 52-53.

Doshi, S. H. (2008). "Making the Sale on Contingent Valuation." Tulane Envtl. L.J. 21: 302-303.

Intergovernmental Panel on Climate Change(1995) Second Assessment:Climate Change 1995

Intergovernmental Panel on Climate Change (2007). Climate Change 2007: Impacts, Adaptation, and Vulnerability, U.N.: 12, 13, 15, 33.

Johansson, P.-O. (1992). "Altruism in Cost-Benefit Analysis." Envtl. \& Res. Econ. 2: 605-613.

Johnston, J. S. (2007). "Desperately Seeking Numbers: Global Warming, Species Loss, and the Use and Abuse of Quantification in Climate Change Policy Analysis." U. Pa. L. Rev. 155: 1908.

Kopczuk, W. and et al. (2005). "The Limitations of Decentralized World Redistribution: An Optimal Taxation Approach." Eur. Econ. Rev. 49: 1054.

Kysar, D. A. (2006). "It Might Have Been: Risk, Precaution and Opportunity Costs." Land Use and Environmental Law Journal 1(22).

Kysar, D. A. and Y.-W. Li (2008). Regulating from Nowhere: Domestic Environmental Law and the Nation-State Subject Cornell Law School Legal Studies Research Paper Series.

Murphy, J. J. and e. al. (2005). "A Meta-Analysis of Hypothetical Bias in Stated Preference Valuation." Envtl. \& Res. Econ. 30.

Nordhaus, W. and J. Boyer (2000). Warming the World, MIT Press.

Posner, E. A. "Agencies Should Ignore Future-Distant Generations," 74 U.CHI. L. REV. 139

Posner, E. A. and C. R. Sunstein (2008). "Dollars for Death" 72 U CHI L REV 579.

Posner, R. A. (2004). Catastrophe: Risk and Response, Oxford University Press. Rachlinski, J, (2000) "The Psychology of Climate Change" U.ILL. L. REV 
Sen, A. (1973). "Behavior and the Concept of Preference." Economica 40.

Sen, A. and B. Williams, Eds. (1982). Utilitarianism and Beyond.

Singer, P. (2002). One World: The Ethics of Globalization, Yale University Press.

Stern, N. (2006). The Economics of Climate Change: The Stern Review, Cambridge

University Press.

Sunstein, C. R. (2005). Laws of Fear: Beyond the Precautionary Principle, Cambridge

University Press.

Zerbe, R. O. (2007). "The Legal Foundation of Cost-Benefit Analysis." Charleston Law Review 2: 115. 